\title{
HUKUM ZAKAT DALAM PERSPEKTIF HUKUM NASIONAL
}

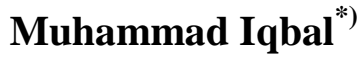 \\ iqbalmiznzh@gmail.com
}

\begin{abstract}
ABSTRAK
Konsepsi zakat sebagai satu bagian dari rukun Islam merupakan salah satu pilar dalam membangun perekonomian ummat tidak hanya bersifat ibadah ritual saja, tetapi mencakup juga dimensi sosial, ekonomi, keadilan dan kesejahteraan manusia. Pemerintah

telah mengatur zakat dalam peraturan perundang-undangan untuk memaksimalkan pengelolaan zakat. Oleh karena itu, dalam penelitian ini dikaji tentang pengaturan hukum zakat dalam peraturan perundangan yang berlaku, hukum zakat dalam Fikih Islam, dan implementasi hukum zakat di Kota Tangerang.

Hasil penelitian menunjukkan pengaturan hukum tentang zakat dalam peraturan perundang-undangan yang berlaku telah diatur bahwa pengelolaan zakat dilaksanakan oleh lembaga zakat, baik di pemerintahan pusat maupun di pemerintahan daerah, tetapi dalam peraturan tersebut belum terperinci diatur tata cara pengelolaan zakat, sehingga pengelolaan zakat belum dapat produktif dan kontributif bagi masyarakat. Hukum zakat sangat mendukung pengelolaan zakat dilakukan secara professional dan produktif untuk mewujudkan kemaslahatan masyarakat dibidang sosial ekonomi. Implementasi hukum zakat dilaksanakan Badan Amil Zakat sesuai dengan peraturan perundangan yang berlaku, baik penerimaan maupun pendistribusian dan pendayagunaan zakat kepada pihak yang berhak, baik dalam bentuk pembiayaan modal usaha maupun dalam bentuk program beasiswa bagi pelajar yang tidak mampu, serta bidang kemanusiaan lainnya yang bertujuan untuk kesejahteraan umat. Namun pengelolaan zakat tersebut belum maksimal karena masih terjadi hambatan seperti masih kurang kepercayaan masyarakat (muzaki) untuk menyalurkan zakatnya kepada BAZDA, juga terbatas kemampuan Sumber Daya Manusia BAZDA.
\end{abstract}

Kata Kunci: Zakat, perspektif, hukum nasional.

*) Dosen Tetap Prodi PAI STAI Asy-Syukriyyah Tangerang 


\title{
ZAKAT LAW OF THE NATIONAL LEGAL PERSPECTIVE \\ Muhammad Iqbal ${ }^{*}$ \\ iqbalmiznzh@gmail.com
}

\begin{abstract}
Conception of zakat as a part of the pillars of Islam is one of the pillars in the economic development of Muslims is not merely ritual worship, but also includes the social, economic, justice and human welfare. The government has set up zakat in legislation to maximize the management of zakat. Therefore, in this study examined about zakat law in the applicable legislation.

The results showed the legal regulation of the charity in the legislation in force stipulates that management has implemented zakat institutions, both in central government or local government, but the regulations have not been detailed in the ordinance regulated the management of zakat, so that management of zakat can not be productive and contributive to society. Zakat law strongly supports the management of zakat is done professionally and productively for the benefit of the community realize the socioeconomic field. Implementation of zakat law Zakat Board (BAZDA) held in accordance with prevailing regulations, both the reception and the distribution and utilization of zakat to those who are entitled, either in the form of venture capital financing or in the form of a scholarship program for students who can not afford, as well as other humanitarian aimed at the welfare of the people. However, the management of zakat is not maximized because there is resistance as public confidence is still lacking (muzaki) to distribute their zakat to BAZDA, also limited the ability of the Human Resources (HR) of BAZDA.
\end{abstract}

Keywords: Zakat, perspective, nasional legal.

\section{A. Pendahuluan}

Salah satu yang menunjang kesejahteraan hidup di dunia dan akherat adalah adanya kesejahteraan sosial-ekonomi. Ini merupakan seperangkat alternatif untuk mensejahterakan umat Islam dari kemiskinan dan kemelaratan. Untuk itu perlu dibentuk lembaga-lembaga sosial Islam sebagai upaya untuk menanggulangi masalah sosial tersebut.

*) Lecturer of PAI STAI Asy-Syukriyyah Study Program in Tangerang 


\section{Jurnal Asy-Syukriyyah}

Syariah pada dasarnya sudah menawarkan beberapa instrumen alternatif dalam pemberdayaan sosial ekonomi seperti zakat, infak, sedekah dan wakaf. Zakat merupakan salah satu instrumental Sistem Ekonomi Islam. Mempunyai hubungannya dengan pemilikan, pemilikan adalah soal yang sangat penting dilihat dari sudut pandang Islam, sebab, selain ia merupakan dari nilai dasar Sistem Ekonomi Islam, ia juga menyangkut hubungan manusia dengan benda atau harta kekayaan yang dimilikinya, mengenai cara memperolehnya, fungsi hak milik dan cara memanfaatkannya. ${ }^{1}$

Zakat merupakan bagian dari syari`at Islam yang memiliki keunikan tersendiri dibandingkan dengan syari at ibadah yang lain. Ia tidak hanya mengandung muatan ibâdah mahdlah secara sempit, tetapi juga sarat dengan muatan ibadah sosial ekonomi. $^{2}$

Pentingnya syari`at zakat dalam Islam dapat dilihat dari kenyataan yang termaktub secara tegas dalam al-Qur`an. Perintah penunaian zakat disebutkan secara berurutan dengan perintah penegakan salat dalam ayat al-Qur`an, yang jumlahnya tidak kurang dari 28 kali. $^{3}$ Dengan demikian dapat dipahami bahwa posisi zakat sejajar dengan penegakan salat. Selain itu, zakat merupakan rukun Islam yang ketiga dari lima rukun Islam.

Begitu pentingnya kewajiban mengeluarkan zakat, khalifah Abu Bakar As Shiddiq memerangi orang-orang yang enggan membayar zakat. ${ }^{4}$ Ini merupakan salah satu tantangan pada awal pemerintahan Abu Bakar As-Shiddiq selain memerangi nabi palsu dan memerangi orang-orang yang murtad. Atas dasar inilah kemudian para ulama menetapkan hukum bunuh bagi kaum muslim yang enggan membayar zakat.

${ }^{1}$ Mohammad Daud Ali, Sistem Ekonomi Islam Zakat dan Wakaf, Jakarta, UI-Press, 1988, hal. 5

${ }^{2}$ Sjechul Hadi Permono, Sumber-Sumber Penggalian Zakat, Pustaka Firdaus, Jakarta, 1992, hal. 44 hal. 803-804.

Ali Audah, Konkordansi al-Qu'ran, Pustaka Litera Antar Nusa, Jakarta, 1997,

${ }^{4}$ Abd al-Khâlik al-Nawâwi, al-Nizhâm al-Mâli fi al-Islâmi, al-Maktabah al-Anjlu al-Mishriyyah, Mesir, 1971, hal. 29 


\section{Jurnal Asy-Syukriyyah}

Bukan hanya itu, al-Qur'an juga mengancam orang-orang yang tidak menunaikan zakat dari harta yang dimilikinya dengan siksa yang pedih, yang artinya:

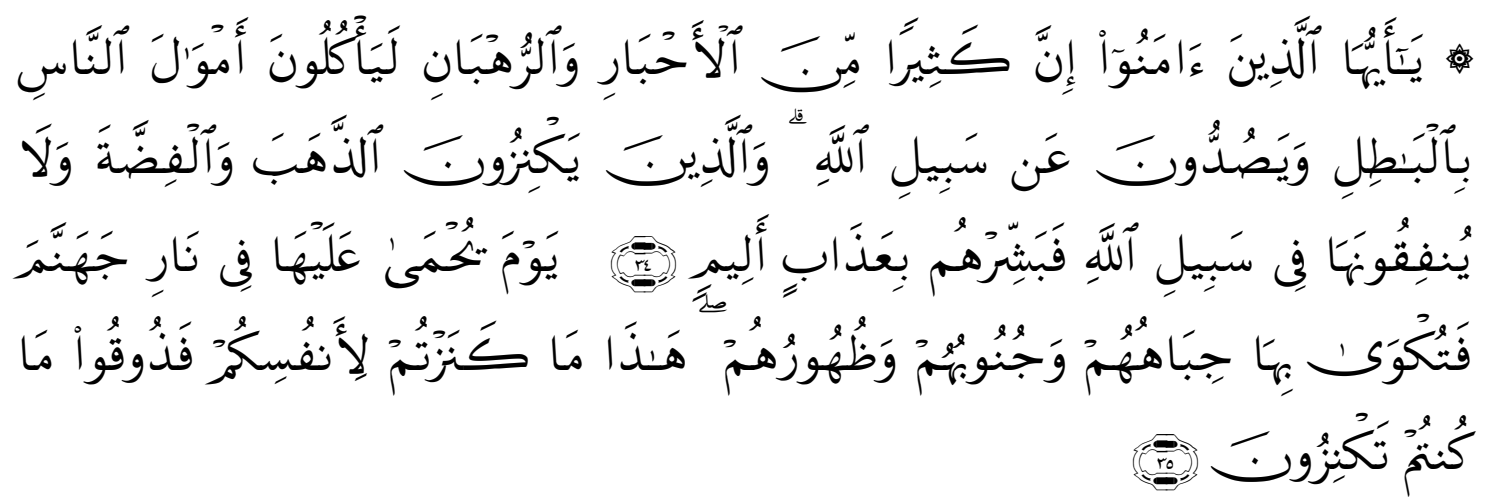

Hai orang-orang yang beriman, Sesungguhnya sebahagian besar dari orang-orang alim Yahudi dan rahib-rahib Nasrani benar-benar memakan harta orang dengan jalan batil dan mereka menghalanghalangi (manusia) dari jalan Allah. dan orangorang yang menyimpan emas dan perak dan tidak menafkahkannya pada jalan Allah, Maka beritahukanlah kepada mereka, (bahwa mereka akan mendapat) siksa yang pedih, Pada hari dipanaskan emas perak itu dalam neraka Jahannam, lalu dibakar dengannya dahi mereka, Lambung dan punggung mereka (lalu dikatakan) kepada mereka: "Inilah harta bendamu yang kamu simpan untuk dirimu sendiri, Maka rasakanlah sekarang (akibat dari) apa yang kamu simpan itu. (QS. At-taubah (9) : 34-35).

Zakat dapat berfungsi sebagai salah satu sumber dana sosial-ekonomi bagi umat Islam. Artinya pendayagunaan zakat yang dikelola oleh Badan Amil Zakat tidak hanya terbatas pada kegiatan-kegiatan tertentu saja yang berdasarkan pada orientasi konvensional, tetapi dapat pula dimanfaatkan untuk kegiatan-kegiatan ekonomi umat, seperti dalam program pengentasan kemiskinan dan pengangguran dengan memberikan zakat produktif kepada mereka yang memerlukan sebagai modal usaha.

Zakat memiliki peranan yang sangat strategis dalam upaya pengentasan kemiskinan atau pembangunan ekonomi. Berbeda dengan sumber keuangan untuk pembangunan yang lain, zakat tidak memiliki dampak balik apapun kecuali ridha dan mengharap pahala dari Allah semata.

Namun demikian, bukan berarti mekanisme zakat tidak ada sistem kontrolnya. Nilai strategis zakat dapat dilihat melalui: Pertama, zakat merupakan panggilan 


\section{Jurnal Asy-Syukriyyah}

agama. Ia merupakan cerminan dari keimanan seseorang. Kedua, sumber keuangan zakat tidak akan pernah berhenti. Artinya orang yang membayar zakat, tidak akan pernah habis dan yang telah membayar setiap tahun atau periode waktu yang lain akan terus membayar. Ketiga, zakat secara empirik dapat menghapus kesenjangan sosial dan sebaliknya dapat menciptakan redistribusi asset dan pemerataan pembangunan. ${ }^{5}$

Zakat diharapkan menjadi suatu sistem yang secara struktural mampu mengatasi masalah kemiskinan dan mendorong perkembangan perekonomian masyarakat. Kemudian nilai etis dalam aspek zakat semestinya terus digali dan ditumbuh kembangkan. Seperti pengentasan kemiskinan dan pemberdayaan ekonomi. Pengkajian nilai etis zakat akan berimplikasi kepada pemikiran tentang bagaimana mengelola sumber-sumber ekonomi secara lebih rasional dan efisien, supaya dampak sosial yang dicita-citakan oleh syari'at zakat tercapai secara optimal. ${ }^{6}$

Zakat dapat dijadikan sebagai sumber keuangan dan pendapatan negara, yang dapat dijadikan sebagai jaminan sosial bagi rakyat yang membutuhkan pertolongan dengan suatu aturan yang jelas. Pemerintah berkewajiban mendistribusikan zakat kepada para mustahiqnya, dan di samping itu pemerintah juga berhak menggunakan dana zakat untuk kepentingan rakyat yang bersifat mendesak. ${ }^{7}$

Konsepsi zakat sebagai satu bagian dari rukun Islam merupakan salah satu pilar dalam membangun perekonomian ummat. Dengan demikian dimensi zakat tidak hanya bersifat ibadah ritual saja, tetapi mencakup juga dimensi sosial, ekonomi, keadilan dan kesejahteraan. Kelahiran Undang-Undang Nomor 38 Tahun 1999 tentang Pengelolaan Zakat (sebagaimana telah diubah dengan Undang-Undang Nomor 23 Tahun 2011 tentang Pengelolaan Zakat) cukup mampu meniupkan angin segar dalam dunia perzakatan di Indonesia. Sebelum dekade ini, pelaksanaan zakat dan

${ }^{5}$ Ahmad M. Saefuddin, Ekonomi dan Masyarakat dalam Perspektif Islam, ed.1 cet.1, CV Rajawali, Jakarta, 1987, hal. 71 .

${ }^{6}$ Dawan Raharjo, Perspektif Deklarasi Mekkah; Menuju Ekonomi Islam, Mizan, Bandung, 1989, hal. 150.

${ }^{7}$ Qutb Ibrâhîm Muhammad, al-Siyâsah al-Mâliyah lî Abî Bakr al-Shiddîq, al-Haiah al- la il hammĩKitâb, Mesir, 1990, hal. 135 


\section{Jurnal Asy-Syukriyyah}

pengelolaannya di tengah masyarakat lebih banyak bersifat lokal dan individual, sehingga terkesan tidak sinergis dan tidak koordinatif serta tidak memenuhi pemerataan penyaluran zakat. Bahkan dalam masa penjajahan Belanda di Indonesia, zakat diselewengkan. ${ }^{8}$

Undang-Undang Nomor 38 Tahun 1999 bertujuan memberikan payung hukum dalam pengelolaan pendistribusian zakat sehingga lebih optimal dalam mewujudkan pemerataan ekonomi dan pembangunan, tetapi perlu ditopang dengan suatu badan pengelola zakat yang modern dan profesional. Hal ini berarti bahwa hukum nasional sudah dapat mengadopsi Hukum Islam.

Reformasi memberikan dampak kebebasan untuk menyampaikan aspirasi dalam konteks hidup berbangsa dan bernegara. Kebebasan beragama merupakan amanat konstitusi. Dalam UUD 45 Pasal 29 ayat (2). Keharusan dan terlibatnya kekuasaan negara dengan agama terlihat dari lahirnya Undang-Undang Nomor 23 Tahun 2011 menggantikan Undang-Undang Nomor 38 Tahun 1999 yang sebelumnya telah menjadi payung hukum pengelolaan zakat. Perancangan mengenai konsep filantropi Islam sebagai alternatif solusi peningkatan kesejahteraan umat kian mengemuka dalam arus wacana publik di negeri ini. Menguatnya kembali estimasi banyak kalangan terhadap implementasi filantropi Islam, baik dalam konteks zakat, infak, sedekah dan wakaf memiliki keterkaitan erat dengan kondisi bangsa yang belum sepenuhnya bangkit dari keterpurukan sebagai dampak krisis ekonomi yang berkepanjangan.

Zakat sebagai bagian dari ibadah juga merupakan bagian dari tatanan ekonomi, sosial dan politik umat Islam. Keterkaitan negara dalam pengelolaan zakat tergantung kepada permasalah dasar yang menjadikan zakat bagian dari hukum diyani yang bersifat qadha' $i{ }^{9}$

8 Adiwarman A. Karim, Ekonomi Islam Suatu Kajian Kontemporer, Gema Insani, Jakarta, 2001, hal. 102

9 A.A Miftah, Zakat Antara Tuntunan Agama dan Tuntutan Hukum, Sultha Thaha Press, Jambi, 2007, hal. 23. 


\section{Jurnal Asy-Syukriyyah}

Pembaharuan hukum Islam dalam bentuk pengkodifikasian menjadi perundangundangan negara adalah bertujuan agar hukum Islam menjadi lebih fungsional dalam kehidupan umat Islam. Begitu juga dengan diberlakukannya Undang-Undang Pengelolaan Zakat diharapkan ada perbaikan dari semua sektor. Bukan hanya perbaikan segi kelembagaan, tetapi dari segi kesadaran masyarakat dalam menyalurkan zakat melalui lembaga juga meningkat. Dengan demikian penghimpunan zakat oleh pengelola zakat juga bertambah sehingga bermanfaat bagi kesejahteraan masyarakat terutama bagi masyarakat miskin.

Undang-Undang Nomor 23 Tahun 2011 tentang Pengelolaan Zakat menjadi payung hukum bagi Badan Amil Zakat Daerah Kabupaten/Kota dalam pengelolaan zakat. Pasal 6 dan Pasal 7 ayat (1) undang-undang tersebut menjelaskan peran BAZNAS menjadi lembaga yang berwenang melakukan tugas pengelolaan zakat secara nasional. Fungsi BAZNAS disebutkan sebagai perencanaan, pelaksana, pengendalian baik dalam pengumpulan, pendistribusian, dan pendayagunaan zakat, serta pelaporan dan pertanggungjawaban pelaksanaan pengelolaan zakat.

\section{B. Pengertian Zakat}

\section{Sejarah Zakat}

Selama 13 tahun hidup dimakkah sebelum hijrah, nabi Muhammad telah13 kali mengalami ramadhan, yaitu dimulai dari ramadhan tahun ke 41 dari kelahiran nabi yang bertepatan dengan bulan agustus $610 \mathrm{M}$, hingga ramadhan tahun ke 53 dari kelahirannya yang bertepatan dengan bulan April tahun $622 \mathrm{M}$. Namun selama itu belum disyariatkan kewajiban mengeluarkan zakat fitri bagi kaum muslimin, dan idul fitrinya juga belum ada atau belum disyari'atkan.

Setelah nabi hijrah ke Madinah, dan menetap selama 17 bulan di sana, pada bulan Sya'ban tahun ke $2 \mathrm{H}$, turunlah ayat 183-184 surah al-baqaroh sebagai dasar disyari'atkannya puasa ramadhan. Tidak lama setelah turunnya ayat itu, masih di bulan ramadhan itu pula, mulai diwajibkan zakat kepada kaum muslimin, 
sebagaimana diterangkan oleh Ibnu Umar dan sejak itulah mulai disebut dengan zakat. "dari Ibnu Umar, sesungguhnya rasulullah saw. Telah mewajibkan zakat fitrah pada bulan ramadhan atas orang-orang sebesar 1 sha' kurma, atau 1 sha' gandum, wajib atas orang merdeka, hamba sahaya, laki-laki dan perempuan, dari kaum muslimin." (H.R. Muslim)

Sejarah pengelolaan zakat oleh amil zakat telah dicontohkan juga sejak zaman Rasulullah Shallalahu 'alaihi wassallam dan para khalifaurrasyidin. Salah satu contohnya adalah ketika Nabi Muhammad Shallalahu 'alaihi wassallam mengutus Muadz bin Jabal ke Yaman dan pada saat beliau menjadi Gubernur Yaman, beliau pun memungut zakat dari rakyat dan disini beliau bertindak sebagai amil zakat sebagaimana sabda Rasulullah Shallalahu 'alaihi wassallam:

"Rasulullah sewaktu mengutus sahabat Mu'adz bin Jabal ke negeri Yaman (yang telah ditaklukkan oleh Islam) bersabda : Engkau datang kepada kaum ahli kitab, ajaklahmereka kepada syahadat, bersaksi bahwa sesungguhnya tidak ada Tuhan selain Allah dan sesungguhnya Nabi Muhammad adalah utusan Allah. Jika mereka telah taat untuk itu, beritahukanlah bahwa Allah mewajibkan kepada mereka melakukan shalat lima waktu dalam sehari semalam. Jika mereka telah taat untuk itu, beritahukanlah kepada mereka bahwa Allah mewajibkan mereka menzakati kekayaan mereka. Zakat itu diambil dari yang kaya dan dibagi-bagikan kepada yang fakir-fakir. Jika mereka telah taat untuk itu, maka hati-hatilah (jangan mengambil) yang baik-baik saja) bila kekayaan itu bernilai tinggi, sedang dan rendah, maka zakatnya harus meliputi nilai-nilai itu. Hindari doanya orang yang madhlum (teraniaya) karena diantara doa itu dengan Allah tidak terdinding (pasti dikabulkan). (HR Bukhari).

Melihat pentingnya zakat dan bagaimana Rasulullah Shallalahu 'alaihi wassallam telah mencontohkan tata cara mengelolanya, dapat disadari bahwa pengelolaan zakat bukanlah suatu hal yang mudah dan dapat dilakukan secara 
individual. Agar maksud dan tujuan zakat, yakni pemerataan kesejahteraan, dapat terwujud, pengelolaan dan pendistribusian zakat harus dilakukan secara melembaga dan terstruktur dengan baik. Hal inilah yang kemudian menjadi dasar berdirinya berbagai Organisasi Pengelola Zakat di berbagai negara, termasuk di Indonesia.

Organisasi Pengelola Zakat di Indonesia terdiri atas Badan Amil Zakat ((BAZ) dan Lembaga Amil Zakat (LAZ). BAZ dibentuk oleh pemerintah di bawah naungan Kementerian Agama, dan tersebar hampir di setiap tingkatan baik tingkat nasional, provinsi, kabupaten/kota, hingga kecamatan. Berbeda dengan BAZ, Lembaga Amil Zakat (LAZ) adalah lembaga yang dibentuk masyarakat yang bertugas untuk mengumpulkan, mendistribusikan, dan mendayagunakan zakat (Undang-Undang Nomor 23 Tahun 2011).

\section{Pengertian Zakat Menurut Bahasa dan Istilah}

Zakat adalah ibadah yang memiliki dua dimensi, yaitu vertikal dan horizontal. Zakat merupakan ibadah sebagai bentuk ketaatan kepada Allah (hablu minallah; vertikal) dan sebagai kewajiban kepada sesama manusia (hablu minannaas; horizontal).

Apabila ditinjau dari segi bahasa, asal kata zakat adalah zaka yang mempunyai pengertian berkah, tumbuh, bersih, dan baik. Sedangkan menurut Lisan Al Arab, arti dasar dari kata zakat, ditinjau dari segi bahasa, adalah suci, tumbuh, berkah dan terpuji yang semuanya digunakan dalam Al Qur'an dan Hadits. ${ }^{10}$

Ditinjau dari segi bahasa, kata zakat merupakan kata dasar (masdar) dan zaka yang berarti berkah, tumbuh bersih, dan baik. ${ }^{11}$ Sesuatu itu zaka, berarti tumbuh dan berkembang, dan seorang itu zaka, berarti orang itu baik.

Menurut Lisan Al-Arab arti sudut bahasa, adalah suci, tumbuh, berkah, dan terpuji, semuanya digunakan di dalam Qur'an dan hadist. Tetapi yang terkuat,

\footnotetext{
${ }^{10}$ Yusuf Qardawi, Hukum Zakat, Litera antar Nusa, Bogor, 1999, hal. 34

${ }^{11}$ Mu'jam Wasith, juz1,hal.398.
} 


\section{Jurnal Asy-Syukriyyah}

menurut Wahidi dan lain-lain, kata dasar zaka berarti bertumbuh dan tumbuh, sehingga bisa dikatakan tanaman itu zaka, artinya tumbuh, sedangkan tiap sesuatu yang bertambah disebut zaka artinya bertambah. Bila satu tanaman tumbuh tanpa cacat, maka kata zaka disini berarti bersih. Dan bila sesorang diberi sifat zaka dalam arti baik, maka berarti orang itu lebih banyak mempunyai sifat yang baik. Seorang itu zaki, berarti seorang yang memiliki lebih banyak sifat-sifat orang baik, dan kalimat "hakim-zaka-saksi" berarti hakim menyatakan jumlah saksi-saksi diperbanyak.

Zakat dari segi istilah fikih berarti "sejumlah harta tertentu yang diwajibkan Allah diserahkan kepada orang-orang yang berhak" ${ }^{\prime 12}$ disamping berarti "mengeluarkan jumlah tertentu itu sendiri." ${ }^{3}$ Jumlah yang dikeluarkan dari kekayaan itu disebut zakat karena yang dikeluarkan itu "menambah banyak, membuat lebih berarti, dan melindungi kekayaan itu dari kebinasaan." Demikian Nawawi mengutip pendapat Wahidi. ${ }^{14}$

Ibnu Taimiah berkata, "Jiwa orang yang berzakat itu menjadi bersih dan kekayaannya akan bersih pula : bersih dan bertambah maknanya." 15

Arti "tumbuh" dan "suci" tidak dipakaikan hanya buat kekayaan, tetapi lebih dari itu, juga buat jiwa orang yang menzakatkannya. Azhari berkata bahwa zakat juga menciptakan pertumbuhan buat orang-orang miskin. Zakat adalah cambuk ampuh yang membuat zakat tidak hanya menciptakan pertumbuhan material dan spiritual bagi orang-orang miskin, tetapi juga mengembangkan jiwa dan kekayaan orang-orang kaya.

Nawawi mengutip dari pengarang Al-Hawi, "Zakat adalah kata Arab yang sudah dikenal sebelum Islam dan lebih banyak dipakai dalam syair-syair daripada diterangkan."

\footnotetext{
${ }^{12}$ Yusuf Qardawi, Op. Cit., hal. 34

${ }^{13}$ Zamakhsyari berkata dalam al-fa'iq, jilid I: 536, cetakan pertama.

${ }^{14}$ Al-Majmu', jilid 5:324.

${ }^{15}$ Kumpulan Fatwa "Syekh, Islam Ibnu Taimiah, Jilid 25:8.
} 
Daud Zahiri berkata, "Kata itu tidak mempunyai asal-usul kebahasaan, hanya dikenal melalui agama." Pengarang Al-Hawi berkata, "Pendapat itu sekalipun salah, tidak sedikit pengaruh positifnya terhadap hukum-hukum zakat."16

Hafidhuddin menjelaskan zakat menurut terminologi syariat (istilah) adalah nama bagi sejumlah harta tertentu yang telah mencapai syarat tertentu yang diwajibkan oleh Allah untuk dikeluarkan dan diberikan kepada yang berhak menerimanya dengan persyaratan tertentu pula. ${ }^{17}$

Dalam buku Pedoman Zakat Departemen Agama RI disebutkan bahwa zakat adalah sesuatu yang diberikan orang sebagai hak Allah SWT kepada yang berhak menerima antara lain para fakir miskin, menurut ketentuan-ketentuan agama Islam. $^{18}$

\section{Syarat-syarat Wajib Zakat}

Dalam mengeluarkan zakat ada beberapa persyaratan yang harus dipenuhi, dimana persyaratan tersebut telah ditentukan secara syariat Islam. Persyaratan yang dimaksudkan adalah syarat yang harus dipenuhi dari sisi wajib zakat (orang yang memberikan zakat) dan dari sisi syarat harta yang dapat dikeluarkan zakatnya. Syarat ini dibagi menjadi dua, yaitu syarat wajib dan syarat sah. Adapun syarat wajib zakat adalah:

a. Merdeka

Seorang budak tidak dikenai kewajiban membayar zakat, karena dia tidak memiliki sesuatu apapun. Semua miliknya adalah milik tuanya.

b. Islam

Seorang non muslim tidak wajib membayar zakat. Adapun untuk mereka yang murtad, terdapat perbedaan pendapat. Menurut Iman Syafii orang murtad

${ }^{16}$ Al-Majmu', Jilid 5:325.

17 Didin Hafiduddin, Zakat Dalam Perekonomian Moderen, Gema Insani, Jakarta, 2002, hal. 28.

${ }^{18}$ Departemen Agama, "Pedoman Zakat 9 seri", Proyek Pembinaan Zakat dan Wakaf Jakarta, UI Press, Jakarta, 1988, hal. 39. 


\section{Jurnal Asy-Syukriyyah}

diwajibkan membayar zakat terhadap hartanya sebelum dia murtad. Sedangkan menurut Imam Hanafi, seorang murtad tidak dikenai zakat terhadap hartanya karena perbuatan riddah-nya (berpaling dari agama Islam) telah menggugurkan kewajiban tersebut.

c. Baligh dan berakal

Anak kecil dan orang gila tidak dikenai zakat pada hartanya, karena keduanya tidak dikenai khitab perintah.

d. Harta tersebut merupakan harta yang memang wajib dizakati, seperti naqdaini (emas dan perak) termasuk juga al-auraq al-naqdiyah (surat-surat berharga), barang tambang dan barang temuan (rikaz), barang dagangan, tanaman-tanaman dan buah-buahan, serta hewan ternak.

e. Harta tersebut telah mencapai nisab (ukuran jumlah).

f. Harta tersebut adalah milik penuh (al-milk al-tam).

Dalam hal ini, harta tersebut berada di bawah kontrol dan di dalam kekuasaan pemiliknya.

g. Telah berlalu satu tahun atau cukup haul (ukuran waktu, masa).

Haul adalah perputaran harta satu nisab dalam 12 bulan qamariyah. Apabila terdapat kesulitan akuntansi karena biasanya angaran dibuat berdasarkan tahun syamsiah, maka boleh dikalkulasikan berdasarkan tahun syamsiyah dengan penambahan volume zakat yang wajib dibayar, dari 2,5\% menjadi 2,575\% sebagai akibat kelebihan hari bulan syamsyiah dari bulan qamariyah.

h. Tidak adanya hutang.

i. Melebihi kebutuhan dasar atau pokok.

Barang-barang yang dimiliki untuk kebutuhan pokok, seperti rumah pemukiman, alat-alat kerajinan, alat-alat industri, sarana transportasi dan angkutan, seperti mobil dan perabotan rumah tangga, tidak dikenakan zakat. Demikian juga uang simpanan yang dicadangkan untuk melunasi hutang, tidak 
diwajibkan zakat, karena seorang kreditor memerlukan uang yang ada ditangannya untuk melepaskan dirinya dari cengkeraman hutang.

j. Harta tersebut harus didapatkan dengan cara yang baik dan halal.

k. Berkembang.

Pengertian berkembang tersebut terbagi menjadi dua, yaitu pertama, bertambah secara kongkrit dan kedua, bertambah secara tidak kongkrit. Berkembang secara kongkret adalah bertambah akibat pembiakan dan perdagangan dan sejenisnya, sedangkan berkembang tidak secara kongkret adalah kekayaan itu berpotensi berkembang baik berada ditangannya maupun ditangan orang lain atas namanya.

Adapun syarat sahnya zakat adalah sebagai berikut:

a. Adanya niat muzakki (orang yang mengeluarkan zakat).

b. Pengalihan kepemilikan dari muzakki ke mustahik (orang yang menerima zakat).

\section{Fungsi dan Peran Zakat}

Fungsi zakat ialah merupakan ibadah muzaki, memenuhi kebutuhan mustahik dan membangun masyarakat. Ada beberapa peran zakat, yakni sebagai berikut:

a. Modal untuk pembangunan masyarakat.

b. Social justice

c. Social equilibrium

d. Social guarantee (jaminan sosial)

e. Social safety (pengaman sosial)

f. Social insurance (asuransi sosial)

g. Oase atau telaga

h. Islam adalah agama amal

\section{Dasar Hukum Zakat}

a. Dalam Al-Qur'an 


\section{Jurnal Asy-Syukriyyah}

Dalam Al-Qur'an terdapat banyak ayat yang menjelaskan tentang kewajiban berzakat, antara lain: Kata zakat dalam banyak definisi disebutkan 30 kali dalam Al-Qur'an, dua puluh tujuh diantaranya disebutkan bersama dalam satu ayat bersama salat atau Allah menyebutkan kewajiban mendirikan shalat beriringan dengan kewajiban menunaikan zakat.

Selain kata zakat, di dalam Al-Qur'an zakat disebut juga dengan nama: Infaq, Shaqadah, Haq atau Afuw.

1) Kata atau sebutan Infaq, dijelaskan dalam surat al-Baqarah ayat 267:

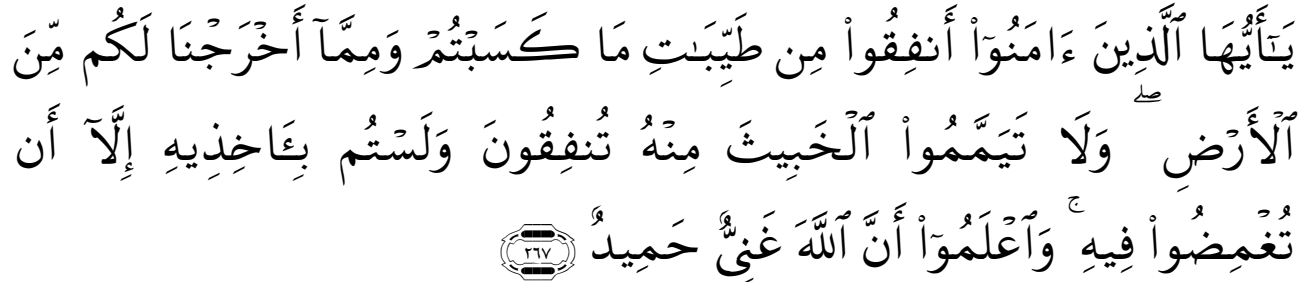

Artinya:

Hai orang-orang yang beriman, nafkahkanlah (di jalan Allah) sebagian dari hasil usahamu yang baik-baik dan sebagian dari apa yang Kami keluarkan dari bumi untuk kamu. dan janganlah kamu memilih yang burukburuk lalu kamu menafkahkan daripadanya, Padahal kamu sendiri tidak mau mengambilnya melainkan dengan memincingkan mata terhadapnya. dan ketahuilah, bahwa Allah Maha Kaya lagi Maha Terpuji.

2) Kata atau sebutan Zakat tercantum dalam surat al-Baqarah ayat 43:

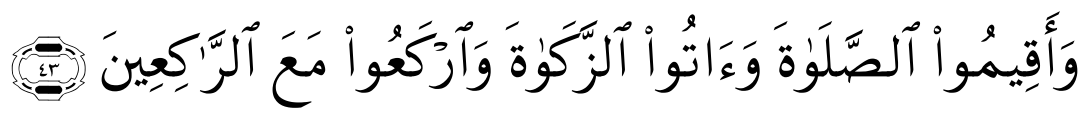

"Dan dirikanlah salat, tunaikanlah zakat dan rukuklah bersama orangorang yang rukuk."

3) Kata atau sebutan Zakat tercantum juga dalam surat At-taubah ayat 103: 


\section{Iurnal Asy-Syukriyyah}

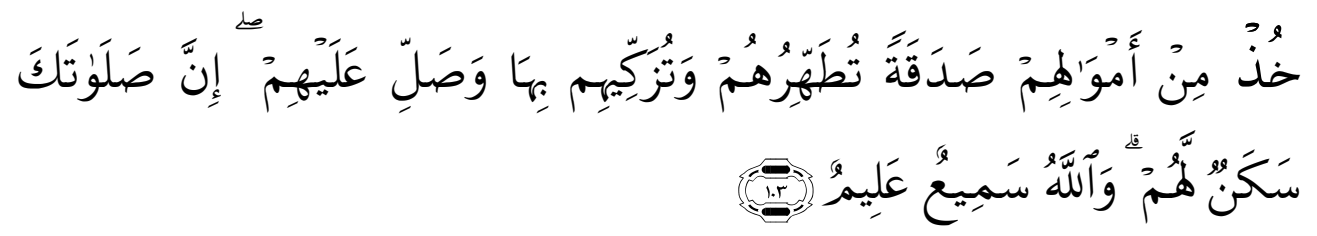

Ambillah zakat dari sebagian harta mereka, dengan zakat itu kamu membersihkan dan mensucikan mereka dan mendoalah untuk mereka. Sesungguhnya doa kamu itu (menjadi) ketenteraman jiwa bagi mereka. dan Allah Maha mendengar lagi Maha mengetahui.

4) Kata atau sebutan Haq, tertera dalam surat al-An'am ayat 141:

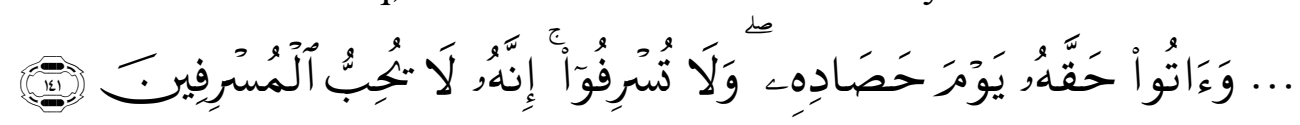

Artinya:

“... dan tunaikanlah haknya di hari memetik hasilnya (dengan disedekahkan kepada fakir miskin); dan janganlah kamu berlebih-lebihan. Sesungguhnya Allah tidak menyukai orang yang berlebih-lebihan".

5) Kata atau sebutan Shaqadah, dijelaskan dalam surat at-Taubah ayat 60:

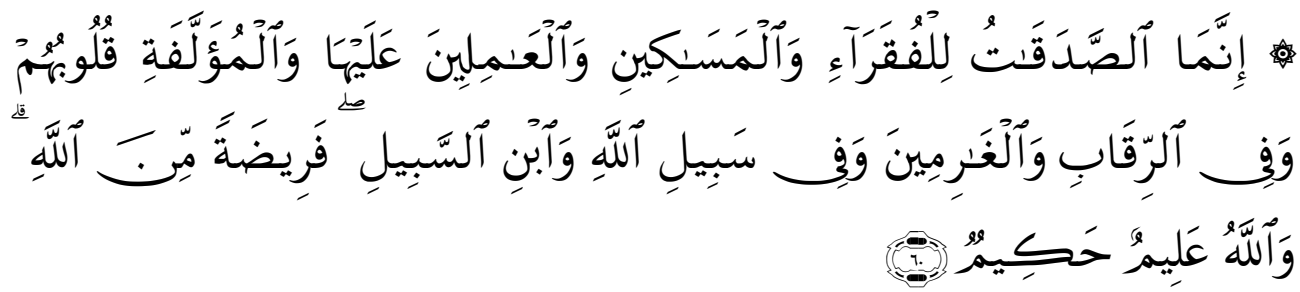

Artinya:

Sesungguhnya shaqadah (zakat-zakat) itu, hanyalah untuk orang-orang fakir, orang-orang miskin, pengurus-pengurus zakat, Para mu'allaf yang dibujuk hatinya, untuk (memerdekakan) budak, orang-orang yang berhutang, untuk jalan Allah dan untuk mereka yuang sedang dalam 


\section{Jurnal Asy-Syukriyyah}

perjalanan, sebagai suatu ketetapan yang diwajibkan Allah, dan Allah Maha mengetahui lagi Maha Bijaksana.

b. Dalam Hadist

Dalam sebuah hadis dijelaskan bahwa ketika Nabi SAW ditanya tentang apakah itu Islam, Nabi menjawab bahwa Islam itu ditegakkan pada lima pilar utama, sebagaimana bunyi hadis berikut ini: "Ketika Nabi SAW ditanya apakah itu Islam? Nabi menjawab: Islam adalah mengikrarkan bahwa tidak ada Tuhan selain Allah dan Muhammad adalah RasulNya, mendirikan salat, membayar zakat, berpuasa pada bulan Ramadhan dan naik haji bagi yang mampu melaksanakannya. (Hadis Muttafaq 'alaih).

c. Dalam Hukum Nasional

Penunaian zakat bagi umat Islam Indonesia telah lama dilaksanakan sebagai dorongan pengalaman dan penyempurnaan ajaran agamanya, walaupun pelaksanaan dan pemberdayaannya masih bersifat tradisional, akan tetapi lambat laun dalam perkembangannya mulai disadari bahwa jumlah umat Islam mayoritas sebenarnya zakat merupakan sumber dana potensial namun belum dimanfaatkan dan dikelola secara baik, terpadu dan optimal dalam rangka meningkatkan kesejahteraan umat. Karena itu, dalam proses perjalanan sejarah, maka pada tanggal 23 September 1999 Bangsa Indonesia telah memiliki hukum berupa Undang-Undang Nomor 38 Tahun 1999 tentang Pengelolaan Zakat, yang pelaksanaan dan pedoman teknis diatur dalam Keputusan Menteri Agama Nomor 581 Tahun 1999 yang telah disempurnakan dengan keputusan Menteri Agama No. 373 tahun 2003 dan Keputusan Direktur Jenderal Bimbingan Masyarakat Nomor D-29 Tahun 2000. Dalam Perkembangannya UndangUndang Zakat disempurnakan lagi yaitu Undang-Undang Nomor 23 Tahun 2011 tentang Pengelolaan Zakat. 


\section{Jurnal Asy-Syukriyyah}

Dengan dikeluarkannya peraturan perundang-undangan tentang pengelolaan zakat tersebut selangkah lebih maju Bangsa Indonesia untuk meningkatkan kesadaran masyarakat dalam penunaian dan pelayanan ibadah zakat khususnya bagi umat Islam, karena zakat sebagai rukun Islam merupakan kewajiban setiap muslim yang mampu untuk membayarnya dan diperuntukkan bagi mereka yang berhak menerimanya. Dengan pengelolaan yang baik (profesional, amanah, transparan dan bertanggung jawab) maka zakat merupakan sumber dana potensial yang dapat dimanfaatkan untuk memajukan bagi kesejahteraan masyarakat terutama pengentasan kemiskinan dan pemberantasan kesenjangan sosial.

\section{Pengaturan Zakat dalam Undang-Undang Nomor 23 Tahun 2011 Tentang Pengelolaan Zakat}

Undang-Undang Nomor 23 Tahun 2011 tentang Pengelolaan Zakat resmi diundangkan dan masuk dalam Lembaran Negara Republik Indonesia bernomor 115 setelah ditandatangani oleh Presiden Susilo Bambang Yudhoyono pada tanggal 25 November 2011. Lahirnya Undang-Undang Nomor 23 Tahun 2011 menggantikan Undang-Undang Nomor 38 Tahun 1999 yang sebelumnya telah menjadi payung hukum pengelolaan zakat. Struktur dari Undang-Undang Pengelolaan Zakat ini terdiri dari 11 Bab dengan 47 Pasal. Tak lupa di dalamnya juga mencantumkan ketentuan pidana dan ketentuan peralihan. ${ }^{19}$

Secara eksplisit tujuan dari Undang-Undang Pengelolaan Zakat adalah untuk mendongkrak dayaguna dan hasilguna pengelolaan zakat, infak dan shadaqah di Indonesia. Karena itu pengelolaan zakat harus dilembagakan (formalisasi) sesuai dengan syariat Islam. Dan harus memenuhi asas-asas amanah, kemanfaatan, keadilan,

\footnotetext{
${ }^{19}$ Undang-Undang Nomor 23 tahun 2011Tentang Pengelolaan Zakat.
} 


\section{Jurnal Asy-Syukriyyah}

kepastian hukum, terintegrasi, dan akuntabilias sehingga dapat meningkatkan efektivitas dan efesiensi pelayanan.

Pengelolaan zakat pada saat menggunakan payung Undang-Undang Nomor 38 Tahun 1999 dirasakan kurang optimal dan memiliki kelemahan dalam menjawab permasalahan zakat di tanah air. ${ }^{20}$ Selain itu pasal-pasal yang termaktub di dalamnya sudah tidak sesuai dengan perkembangan kebutuhan hukum dalam masyarakat sehingga butuh pembaruan. Karena itu di dalam Undang-Undang Nomor 23 Tahun 2011 pengelolaan zakat lebih terintegrasi dan terarah dengan mengedepankan perencanaan, pengumpulan, pendistribusian, dan pendayagunaan. Problem mendasar yang dihadapi pada rezim zakat terdahulu adalah adanya kesimpangsiuran siapa yang harus menjadi leading sector. ${ }^{21}$ Dalam undang-undang sebelumnya antara Badan Amil Zakat (BAZ) dan Lembaga Amil Zakat (LAZ) dalam relasi sejajar, bahkan dalam situasi tertentu cenderung pada posisi saling berhadap-hadapan (vis a vis). Sehingga memunculkan dikotomi antara dua lembaga tersebut. BAZ seolah-olah milik pemerintah, sedang LAZ punya masyarakat. Keadaan semacam itu dinilai kurang kondusif sehingga potensi yang begitu besar terabaikan sehingga pengelolaan maupun pendistribusian tidak memiliki arah, dimana saja wilayah mustahik yang lebih krusial. Menurut Gondon Radityo Gambiro salah satu anggota dewan dari Fraksi Partai Demokrat, ada dua alasan pokok kenapa Undang-Undang Zakat yang lama diganti. Pertama, masyarakat belum memperoleh manfaat secara signifikan atas pengelolaan zakat, baik bagi muzaki maupun mustahik. Kedua, kebutuhan akan pengaturan pengelolaan zakat yang komprehensip demi tercapainya tujuan pengelolaan zakat di Indonesia. Disamping itu penyaluran jadi kurang tertata dan cenderung sporadis, karena masing-masing organisasi pengelola zakat seperti berjalan sendiri-sendiri. Melihat kenyataan yang demikian itu, undang-undang pengelolaan zakat yang baru,

${ }^{20}$ HM.Busro anggota Komisi VIII DRR-RI dari Fraksi Golongan Karya (Golkar)

${ }^{21}$ Iskan Qolba Lubis, Anggota Komisi VIII DPR RI dari fraksi PKS (Partai Keadilan Sejahtera). Jurnal INFOZ+, Edisi 16 Th VII Januari- Februari 2012, hal. 4 


\section{Jurnal Asy-Syukriyyah}

kini lebih memberikan kepastian dan tanggungjawab baru kepada sebuah lembaga yang (dipandang) mampu mengkoordinasikan kepentingan.

Dalam Pasal 6 dan Pasal 7 ayat (1) Undang-Undang Nomor 23 Tahun 2011 dijelaskan, ${ }^{22}$ peran BAZNAS menjadi lembaga yang berwenang melakukan tugas pengelolaan zakat secara nasional. Fungsi BAZNAS disebutkan sebagai perencanaan, pelaksana, pengendalian baik dalam pengumpulan, pendistribusian, dan pendayagunaan zakat. Selain itu, pelaporan dan pertanggungjawaban pelaksanaan pengelolaan zakat. Dalam hal ini BAZNAS cukup punya kewenangan yang lebih. Jika kemampuan BAZNAS pada Undang-Undang Nomor 38 Tahun 1999 memiliki kewenangan yang terbatas, sehingga dari sisi pengumpulan maupun pendistribusian kalah jauh dengan LAZ. Akan tetapi dengan kewenangan yang diberikan sekarang BAZNAS akan sangat leluasa dengan memiliki hirarki dan jaringan hingga tingkat struktur yang paling bawah.

Salah satu hal terpenting dalam Undang-Undang Nomor 23 Tahun 2011 tentang Pengelolaan Zakat di antaranya adalah terkait dengan penguatan kelembagaan. Dalam Undang-undang ini BAZNAS (Badan Amil Zakat Nasional) disebutkan sebagai lembaga pemerintah non struktural yang merupakan perpanjangan tangan dari pemerintah. Dalam hal ini secara teknis BAZNAS di bawah koordinasi Kementerian Agama. Jika pada Undang-Undang Nomor 38 Tahun 1999 yang duduk di BAZNAS disebut sebagai pengurus, maka di dalam Undang-Undang Nomor 23 Tahun 2011

${ }^{22}$ Pasal 6 BAZNAS merupakan lembaga yang berwenang melakukan tugas pengelolaan zakat secara nasional. Pasal 7 (1) Dalam melaksanakan tugas sebagaimana dimaksud dalam Pasal 6, BAZNAS menyelenggarakan fungsi: a. perencanaan pengumpulan, pendistribusian, dan pendayagunaan zakat; $b$. pelaksanaan pengumpulan, pendistribusian, dan pendayagunaan zakat; c. pengendalian pengumpulan, pendistribusian, dan pendayagunaan zakat; dan $d$. pelaporan dan pertanggungjawaban pelaksanaan pengelolaan zakat. (2) Dalam melaksanakan tugas dan fungsinya, BAZNAS dapat bekerja sama dengan pihak terkait sesuai dengan ketentuan peraturan perundang-undangan. (3) BAZNAS melaporkan hasil pelaksanaan tugasnya secara tertulis kepada Presiden melalui Menteri dan kepada Dewan Perwakilan Rakyat Republik Indonesia paling sedikit 1 (satu) kali dalam 1 (satu) tahun 


\section{Jurnal Asy-Syukriyyah}

tentang Pengelolaan Zakat, sebutan mereka tidak lagi sebagai pengurus, tetapi anggota komisioner.

Proses perekrutan anggota komisioner BAZNAS akan dilakukan dengan terlebih dahulu membentuk tim khusus. "Tugas tim ini secara terperinci akan dijabarkan dalam Peraturan Pemerintah (PP) yang saat ini masih dalam tahap penyusunan. Sementara pengangkatan dan pemberhentian anggota komisioner dilakukan oleh Presiden atas usul menteri. Anggota komisoner BAZNAS akan disaring oleh tim seleksi yang prosesnya terbuka. Siapapun yang memenuhi syarat maka boleh ikut mendaftar. Tim pansel (panitia seleksi) nantinya bukan dari internal Kementerian Agama, tetapi dari berbagai unsur masyarakat seperti tokoh masyarakat, profesional, intelektual dan sebagainya. $^{23}$

BAZNAS sebagai lembaga yang diatur secara definitif dalam undang-undang juga memiliki sifat mandiri, sebagaimana disebut Pasal 5 ayat (3) Undang-Undang Nomor 23 Tahun 2011 BAZNAS merupakan lembaga pemerintah nonstruktural yang bersifat mandiri. Namun, selain sifat mandiri, ada dua unsur lain yang diatur dalam pasal tersebut, yaitu BAZNAS sebagai lembaga pemerintah non-struktural, dan bertanggungjawab kepada Presiden melalui Menteri Agama. Ketentuan ini mengakibatkan pertentangan dan kerancuan. Pertentangan antara lembaga pemerintah non struktural dan sifat mandiri suatu lembaga dengan bentuk tanggungjawabnya kepada Presiden melalui Menteri. Sifat mandiri dari lembaga yang dibentuk secara definitif dari suatu undang-undang harus lepas dari kekuasaan eksekutif, legislatif, maupun yudikatif. Kedudukan Presiden dalam Pasal 5 ayat (3) berkedudukan sebagai Kepala Pemerintahan, dan dibantu oleh Menteri dalam pelaksanaan tugasnya. Sehingga, dengan adanya ketentuan bahwa BAZNAS bertanggungjawab kepada Presiden melalui Menteri, sudah mengkonstruksikan bahwa kedudukan BAZNAS

${ }^{23}$ Isbir Fadly, Kasubdit Kelembagaan Direktorat Pemberdayaan Zakat Kemenag, Jurnal INFOZ+, Edisi I 16 Th VII Januari - Februari 2012, hal. 8. 


\section{Jurnal Asy-Syukriyyah}

berada di bawah kekuasaan eksekutif, yang secara otomatis mereduksi makna dari sifat mandiri pada BAZNAS.

Pendirian BAZNAS sangat rentan dengan politisasi kelompok tertentu, karena dalam Undang-Undang Nomor 23 Tahun 2011, disebutkan bahwa anggota BAZNAS hanya terdiri dari sebelas orang dengan perincian tiga orang dari unsur pemerintah yang ditunjuk dari kementerian/instansi yang berkaitan dengan pengelolaan zakat, dan delapan orang dari unsur masyarakat yang terdiri dari ulama, tenaga profesional, dan tokoh masyarakat Islam.

Fase rekrutmen ini menjadi persoalan yang sangat krusial dan harus diperhatikan dan diawasi karena dikhawatirkan akan muncul adalah anggota titipan yang memiliki kepentingan tertentu. Zakat adalah persoalan ummat maka keterwakilan secara demokratis harus dipertimbangkan. Jika pola rekrutmennya tidak transparan maka BAZNAS bisa disalahgunakan dan akhirnya didominasi oleh kepentingan pemerintah. Di samping itu, jumlah komisioner yang sampai mencapai sebelas orang yang dinilai terlalu gemuk untuk lembaga sejenis BAZNAS. Hal menunjukkan produk legislasi ini memberikan ruang yang sangat lebar adanya ruang akomodasi kepentingan, maka akan sangat rentan menjadi ajang politisasi kepentingan. Apalagi dengan kewenangan BAZNAS yang begitu powerfull sangat rentan dengan penyalahgunaan dan dijadikan sebagai alat bagi kepentingan kepala daerah (incumbent) sehingga berbelok dari misi awal dan tujuan zakat.

Pasal 3 Undang-Undang Nomor 23 Tahun 2011 tentang Pengelolaan Zakat menyebutkan pengelolaan zakat bertujuan:

1. Meningkatkan efektivitas dan efisiensi pelayanan dalam pengelolaan zakat; dan

2. Meningkatkan manfaat zakat untuk mewujudkan kesejahteraan masyarakat dan penanggulangan kemiskinan. 


\section{Jurnal Asy-Syukriyyah}

Oleh karena itu, anggota yang mengisi BAZNAS harus orang-orang yang benarbenar kompeten, punya kapabilitas dan bekerja keras supaya lembaga tersebut bisa berjalan secara optimal sehingga dapat dipercaya oleh masyarakat dan jangan sampai ummat merasa kekecewaan. Karena selain sebagai koordinator, pengawasan, pelaporan BAZNAS juga memiliki fungsi pelaksana operasional atau sebagai operator zakat yang dapat memicu timbulnya konflik kepentingan dengan lembaga amil zakat lain terutama yang dikelola oleh masyarakat. Sehingga mudah menimbulkan disfungsi karena mengurangi peranserta masyarakat. Disamping itu BAZNAS juga berfungsi untuk mengawasi LAZ agar lebih transparan dan sesuai dengan apa yang dikehendaki oleh muzaki sehingga memang harus ada verifikasi secara lebih ketat dan profesional dalam menjalankan fungsinya. Adapun Badan atau Lembaga yang ditetapkan sebagai penerima zakat atau sumbangan meliputi:

1. Satu Badan Amil Zakat Nasional (BAZNAS),

2. Lima belas Lembaga Amil Zakat (LAZ),

3. Tiga Lembaga Amil Zakat, Infaq, dan Shaaqah (LAZIS) dan

4. Satu Lembaga Sumbangan Agama Kristen Indonesia.

Adapun nama-nama Badan atau Lembaga penerima zakat atau sumbangan tersebut adalah sebagai berikut:

1. Badan Amil Zakat Nasional (BAZNAS).

2. LAZ Dompet Dhuafa Republika.

3. LAZ Yayasan Amanah Takaful.

4. LAZ Pos Keadilan Peduli Umat.

5. LAZ Yayasan Baitulmaal Muamalat.

6. LAZ Yayasan Dana Sosial Al Falah.

7. LAZ Baitul Maal Hidayatullah.

8. LAZ Persatuan Islam.

9. LAZ Yayasan Baitul Mal Umat Islam PT Bank Negara Indonesia. 


\section{Jurnal Asy-Syukriyyah}

10. LAZ Yayasan Bangun Sejahtera Mitra Umat.

11. LAZ Dewan Da'wah Islamiyah Indonesia.

12. LAZ Yayasan Baitul Maal Bank Rakyat Indonesia.

13. LAZ Yayasan Baitul Maal wat Tamwil.

14. LAZ Baituzzakah Pertamina.

15. LAZ Dompet Peduli Umat Daarut Tauhiid (DUDT).

16. LAZ Yayasan Rumah Zakat Indonesia.

17. LAZIS Muhammadiyah.

18. LAZIS Nahdlatul Ulama (LAZIS NU).

19. LAZIS Ikatan Persaudaraan Haji Indonesia (LAZIS IPHI).

20. Lembaga Sumbangan Agama Kristen Indonesia (LEMSAKTI). ${ }^{24}$

Undang-Undang Nomor 23 Tahun 2011 juga mengatur mekanisme pembentukan Badan atau Lembaga Zakat melalui surat keputusan menteri dan persyaratan pemberian izin bagi Lembaga Amil Zakat (LAZ) sehingga memudahkan BAZNAS mengontrol dan mengawasi LAZ yang tumbuh dan berkembang secara liar ditengahtengah masyarakat (Pasal 18). Sehingga setiap orang dilarang dengan sengaja bertindak sebagai amil zakat dengan melakukan pengumpulan, pendistribusian, atau pendayagunaan zakat tanpa izin pejabat yang berwenang dan akan dikenakan sanksi.

Pasal 38 Undang-Undang Nomor 23 Tahun 2011 tentang Pengelolaan Zakat, menyatakan "setiap orang dilarang dengan sengaja bertindak selaku amil zakat melakukan pengumpulan, pendistribusian, atau pendayagunaan zakat tanpa izin pejabat yang berwenang". Selanjutnya dalam Pasal 41 disebutkan "setiap orang yang dengan sengaja dan melawan hukum melanggar ketentuan sebagaimana dimaksud dalam Pasal 38 dipidana dengan pidana kurungan paling lama 1 (satu) tahun dan/atau pidana denda paling banyak Rp 50.000.000,00 (lima puluh juta rupiah).”

\footnotetext{
${ }^{24}$ http://www.forumzakat.net/majalah/Infoz+\%20Edisi\%2016\%20Januari-Pebruari\% 202012.pdf
} 


\section{Jurnal Asy-Syukriyyah}

\section{Kesimpulan}

Pengaturan hukum zakat dalam Undang-Undang Nomor 23 Tahun 2011 tentang Pengelolaan Zakat telah mengatur zakat untuk dilaksanakan oleh lembaga zakat baik di tingkat pusat maupun di tingkat daerah. Pengelolaan zakat lebih terintegrasi dan terarah dengan mengedepankan perencanaan, pengumpulan, pendistribusian, dan pendayagunaan.

Hal terpenting dalam Undang-Undang Nomor 23 Tahun 2011 tentang Pengelolaan Zakat di antaranya adalah terkait dengan penguatan kelembagaan. Dalam Undang-undang ini BAZNAS (Badan Amil Zakat Nasional) disebutkan sebagai lembaga pemerintah non struktural yang merupakan perpanjangan tangan dari pemerintah dan sebagai lembaga yang diatur secara definitif dalam undang-undang yang memiliki sifat mandiri 


\section{Jurnal Asy-Syukriyyah}

\section{DAFTAR PUSTAKA}

\section{A. Buku}

Ali, Mohammad Daud, Sistem Ekonomi Islam Zakat dan Wakaf, cet. 1. UI Press, Jakarta, 1988.

al-Nawâwi, Abd al-Khâlik, al-Nizhâm al-Mâli fi al-Islâmi, al-Maktabah al-Anjlu alMishriyyah, Mesir, 1971.

Audah, Ali, Konkordansi al-Qu'ran, Pustaka Litera Antar Nusa, Jakarta, 1997.

Hafidhuddin, Didin, Zakat dalam Perekonomian Modern, Gema Insani, Jakarta, 2002.

Karim, Adiwarman A., Ekonomi Islam Suatu Kajian Kontemporer, Gema Insani, Jakarta, 2001.

Miftah, A.A, Zakat Antara Tuntunan Agama dan Tuntutan Hukum, Sultha Thaha Press, Jambi, 2007.

Muhammad, Qutb Ibrâhîm, al-Siyâsah al-Mâliyah lî Abî Bakr al-Shiddîq, al-Haiah alla il hammī-Kitâb, Mesir, 1990.

Permono, Sjechul Hadi, Sumber-Sumber Penggalian Zakat, Pustaka Firdaus, Jakarta, 1992.

Qardawi, Yusuf, Hukum Zakat, Litera antar Nusa, Bogor, 1999.

Raharjo, Dawan, Perspektif Deklarasi Mekkah; Menuju Ekonomi Islam, Mizan, Bandung, 1989.

Saefuddin, Ahmad M., Ekonomi dan Masyarakat dalam Perspektif Islam, ed.1 cet.1, CV Rajawali, Jakarta, 1987.

\section{B. Makalah, Artikel, Jurnal dan Karya Ilmiah}

Departemen Agama, Pedoman Zakat 9 seri, Proyek Pembinaan Zakat dan Wakaf Jakarta, UI Press, Jakarta, 1988.

http://www.forumzakat.net/majalah/Infoz+\%20Edisi\%2016\%20Januari-Pebruari\% 202012.pdf

Lubis, Iskan Qolba, jurnal INFOZ+, Edisi 16 Th VII Januari- Februari 2012. 


\section{Jurnal Asy-Syukriyyah}

Qardawi, Yusuf, terjemahan Salman Harun, Didin Hafidhuddin, dan Hasanuddin, Hukum Zakat Studi Komparatif Mengenai Status dan Filsafat Zakat Berdasarkan Qur'an dan Hadis, diterbitkan atas kerjasama Penerbit Utara AntarNusa dan Penerbit Mizan, PT Mitra Kerjaya, Jakarta, cetakan kelima, 1999.

\section{Peraturan Perundang-Undangan}

Undang-Undang Dasar 1945

Undang-Undang Nomor 23 Tahun 2011 tentang Pengelolaan Zakat 